\author{
Peter J.Strouse \\ Michael Caplan \\ Clyde L. Owings
}

\section{Extracranial soft-tissue swelling: a normal postmortem radiographic finding or a sign of trauma?}

Received: 17 December 1997

Accepted: 16 March 1998

P.J.Strouse (

Section of Pediatric Radiology,

C.S. Mott Children's Hospital,

University of Michigan Medical Center,

1500 East Medical Center Drive,

Ann Arbor, MI 48109-0252, USA

M. Caplan

Department of Pathology,

University of Michigan Medical School,

Ann Arbor, Michigan, USA

C.L. Owings

Department of Pediatrics

and Communicable Diseases,

C.S. Mott Children's Hospital, Ann Arbor, Michigan, USA

\begin{abstract}
Objective. To determine if extracranial soft-tissue swelling is an expected postmortem finding or a sign of trauma.

Materials and methods. Extracranial soft-tissue thickness was measured at 5 standardized locations on postmortem skull films obtained of 18 infants with no evidence of trauma on autopsy. The same measurements were performed on the skull films of 100 living children, all less than 3 years old and without clinical history of trauma.

Results. Extracranial soft tissues measured only slightly greater in the postmortem group than on films of living children; however, the differ-
\end{abstract}

ence did achieve statistical significance.

Conclusion. Minimal extracranial soft-tissue swelling is a normal finding on a postmortem skeletal survey. The presence of substantial or asymmetric extracranial soft-tissue swelling should be viewed with suspicion for trauma.

\section{Introduction}

Head trauma is unfortunately common in the setting of child abuse. External signs of trauma due to child abuse can be minimal, even in the presence of life-threatening or fatal injuries. Most investigations have focused on intracranial injury or skull fractures [1-4]. Children suffering blunt head trauma with or without intracranial injury or skull fracture may also have associated extracranial soft-tissue swelling. Extracranial soft-tissue swelling may not be readily evident clinically, particularly in a child with a substantial amount of hair.

We recently encountered a 25-month-old child, fatally abused, who showed substantial extracranial soft-tissue swelling (maximum thickness of $15 \mathrm{~mm}, 12 \mathrm{~mm}$ at right lateral versus $7 \mathrm{~mm}$ at left lateral) on a postmortem skeletal survey. As the child had only survived a short time after arriving at the hospital, neither a premortem skeletal survey nor computed tomography
(CT) of the head were performed. The child had had a skeletal survey 11 months previously when he presented with a femur fracture. Visible extracranial soft tissues at that time were of normal thickness (maximum thickness of $6 \mathrm{~mm}$ ). During investigation of this case, the question was posed as to whether the soft-tissue swelling was an expected postmortem finding or evidence of trauma and possible child abuse. Although autopsy results confirmed a traumatic injury in this case, to investigate this query, we performed the following study.

\section{Materials and methods}

At our institution, skeletal surveys are routinely obtained in all cases of presumed sudden infant death syndrome (SIDS) to exclude occult traumatic injuries from child abuse. The radiology database was searched for a $3 \frac{1}{2}$-year period to identify all skeletal surveys of children with unexplained deaths and/or presumed SIDS. Medical records were reviewed to approximate the time be- 
Table 1 Extracranial soft-tissue measurements ( $S D$ standard deviation; $\max$ maximum measurement as defined in text, $N S$ not statistically significant)

\begin{tabular}{|c|c|c|c|c|c|c|c|}
\hline & $\begin{array}{l}\text { Age } \\
\text { (months) }\end{array}$ & $\begin{array}{l}\text { Right } \\
\text { lateral } \\
(\mathrm{mm})\end{array}$ & $\begin{array}{l}\text { Left } \\
\text { lateral } \\
(\mathrm{mm})\end{array}$ & $\begin{array}{l}\text { Anterior } \\
(\mathrm{mm})\end{array}$ & $\begin{array}{l}\text { Vertex } \\
(\mathrm{mm})\end{array}$ & $\begin{array}{l}\text { Posterior } \\
(\mathrm{mm})\end{array}$ & $\begin{array}{l}\text { Maxi- } \\
\text { mum } \\
(\mathrm{mm})\end{array}$ \\
\hline \multicolumn{8}{|l|}{ Postmortem $(n=18)$} \\
\hline Mean & 3.4 & 3.3 & 3.2 & 4.5 & 3.9 & 4.1 & 5.0 \\
\hline SD & & 1.2 & 0.9 & 0.9 & 1.1 & 1.0 & 1.6 \\
\hline Max & & 7 & 5 & 6 & 7 & 6 & 9 \\
\hline \multicolumn{8}{|c|}{ Living children $(n=100)$} \\
\hline Mean & 8.6 & 2.8 & 2.8 & 4.3 & 3.0 & 3.4 & 4.4 \\
\hline SD & & 0.7 & 0.6 & 1.0 & 0.8 & 0.8 & 1.0 \\
\hline Max & & 5 & 4 & 7 & 6 & 6 & 7 \\
\hline $\begin{array}{l}\text { vs. postmortem group } \\
(P \text { value })\end{array}$ & & 0.005 & 0.04 & NS & $<10^{-4}$ & $<10^{-3}$ & 0.02 \\
\hline \multicolumn{8}{|c|}{ Age-matched living children $(n=18)$} \\
\hline Mean & 3.4 & 2.5 & 2.7 & 4.2 & 3.1 & 3.2 & 4.3 \\
\hline SD & & 0.5 & 0.6 & 1.0 & 0.6 & 0.8 & 0.8 \\
\hline Max & & 3 & 4 & 6 & 4 & 5 & 6 \\
\hline $\begin{array}{l}\text { vs. postmortem group } \\
(P \text { value })\end{array}$ & & 0.01 & NS & NS & 0.005 & 0.005 & NS \\
\hline
\end{tabular}

Table 2 Lateral soft tissues

\begin{tabular}{lcc}
\hline & Postmortem & Living children \\
\hline Right = left & 11 & 78 \\
1-mm difference & 5 & 22 \\
2-mm difference & 1 & 0 \\
3-mm difference & 1 & 0 \\
>-mm difference & 0 & 0 \\
Total & 18 & 100 \\
\hline
\end{tabular}

tween death and obtaining the films. By these estimates, the skeletal surveys were obtained from 3 to 48 hours (mean 19 hours) of the approximate time of death. Autopsy results were reviewed to exclude any children who may have shown signs of abuse. Eighteen children were initially identified and none were excluded. Causes of death were: SIDS - 12 children, complications of bronchial asthma -1 , hypoglycemia -1 , carbon monoxide poisoning -1 , coronary artery anomaly -1 , right ventricular dysplasia -1 , and pneumonia/bronchiolitis -1 .

Most postmortem skeletal surveys are performed with portable equipment in the morgue. Standard positioning is with a 40-inch source-to-image distance. Using a hot light and ruler, extracranial soft tissues were measured in three locations on the lateral film: $3 \mathrm{~cm}$ above the orbit roof, $3 \mathrm{~cm}$ posterior to the coronal sutures, and directly over the torcula. On the anteroposterior film measurements were obtained bilaterally $3 \mathrm{~cm}$ superior to the petrous apex. The maximal extracranial soft-tissue thickness observed on either view was also recorded, with the stipulation that it be cephalad to the lateral site of measurement on the AP view or between the anterior and posterior sites of measurement on the lateral view.

For comparison, similar measurements were obtained from the skull films of 100 living children, all less than three years of age. The range of age in this group was older than in the postmortem group in order to include patients similar in age to the index case. To identify these children, the radiology database was searched for skull films. All children with a history or findings of trauma, mass and shunt placement were excluded. Skull films obtained within two weeks of birth were excluded. The remainder was main- ly composed of films obtained to evaluate possible abnormalities of head size and/or shape. Any child with radiographic findings suggestive of craniosynostosis was also excluded, as it was uncertain how this might affect the extracranial soft tissue and because it could cause some asymmetry of the lateral measurements. All films were obtained within the pediatric radiology department. Standard positioning for skull films in the department is also with a 40-inch source-to-image distance.

Measurements obtained in the two groups were tabulated and compared using Student's $t$-tests. A $P$ value of $<0.5$ was considered statistically significant. Because the age distribution of the living children was considerably older than the postmortem group, the analysis was repeated using a group of 18 age-matched controls selected randomly from the living children group.

\section{Results}

Mean extracranial soft-tissue measurements and standard deviations are listed within Table 1 for the postmortem, living children, and age-matched living children groups. Measurements of extracranial soft-tissue thickness were slightly larger at all locations in the postmortem group than in the living children group and the agematched living children group. At several locations differences achieved statistical significance (Table 1). In most children in both groups lateral soft tissues were of symmetric thickness (Table 2). Slight asymmetry was noted in the lateral soft-tissue thickness on two of the postmortem studies (2- and 3-mm differences).

\section{Discussion}

As external signs of trauma in the setting of child abuse can be minimal or frankly absent, it is the obligation of the radiologist to recognize subtle radiographic findings 
that may be indicative of trauma. Although extracranial soft-tissue swelling is often clinically evident, it can be occult, particularly in a child with a full head of hair. Extracranial soft tissues should be assessed on all skeletal surveys performed to check for possible child abuse. Radiographic technique should be such that extracranial soft tissues can be seen. Use of a 'hot light' is essential in many cases. By identifying extracranial soft-tissue swelling on films of a living child, the radiologist may suspect trauma or prompt further investigation for possible trauma.

It appears that a minimal degree $(2-3 \mathrm{~mm}$ difference) of asymmetry of the lateral soft tissues may be seen occasionally on postmortem studies. A greater degree of asymmetry infers a traumatic etiology of the soft-tissue swelling, as in the case which prompted our investigation. Asymmetric soft-tissue swelling of at least $4 \mathrm{~mm}$ will accompany all acute skull fractures [5].

Substantial extracranial soft-tissue swelling is not a normal expected finding on a postmortem skeletal survey performed shortly after death. Although dependent edema does occur, it does not appear to be radiographically evident to a substantial degree. By identifying softtissue swelling on a postmortem survey, the radiologist can suggest that pre-mortal trauma may have occurred and offer guidance to the pathologist in subsequent investigation.

Acknowledgments The authors thank Evelyn Rogers RT(R) for her assistance in obtaining pathology records for review and Betty Reohr for her secretarial assistance.

\section{References}

1. Kleinman PK (1987) Head trauma. In: Kleinman PK (ed) Diagnostic imaging of child abuse. Williams and Wilkins, Baltimore, pp 159-199
2. Harwood-Nash DC (1992) Abuse to the pediatric central nervous system. AJNR 13: 569-575

3. Cohen RA, Kaufman RA, Myers PA, Towbin RB (1986) Cranial computed tomography in the abused child with head injury. AJR 146: 97-102
4. Meservy CJ, Towbin R, McLaurin RL, Myers PA, Ball W (1987) Radiographic characteristics of skull fractures resulting from child abuse. AJR 149: 173-175

5. Kleinman PK, Spevak MR (1992) Soft tissue swelling and acute skull fractures. J Pediatr 127: 737-739 